\title{
Using Environmental and Social Information in Lending Decisions
}

\author{
Omer M Elsakit ${ }^{1} \&$ Andrew C Worthington ${ }^{1}$ \\ ${ }^{1}$ Department of Accounting, Finance and Economics, Griffith Business School, Griffith University, Australia \\ Correspondence: Omer M Elsakit, Department of Accounting, Finance and Economics, Griffith Business School, \\ Griffith University, Australia. Tel: 61-43-271-6812. E-mail: O.elsakit@griffith.edu.au
}

Received: September 6, 2012

Accepted: November 15, 2012 Online Published: December 10, 2012

doi:10.5539/ijef.v5n1p112

URL: http://dx.doi.org/10.5539/ijef.v5n1p112

\begin{abstract}
There is no doubt that collecting and analysing information is the key element in the process of decision making. Lending decisions, taken by banks, are not exception. In order to ensure that lending decisions are serving banks' goals, the process of taking such decisions involves, inter alia, gathering and analysing information about the prospective and actual clients, who are seeking loans. Such information is mainly related to the financial performance of banks' clients. The recent trend of considering information other than financial one, particularly in developed countries, seems to be basically enforced, rather than promoted, by power of the law. This can be noted in the increasing interest of banks in environmental information, while social information is still, to some extent, far from the attention of such banks. Other factors, such as religious instructions are suggested to play a role in encouraging banks to consider social information. In the case of developing countries, social and environmental information alike seems to be out of banks attention due to many factors including the absence of related laws and the weakness of desire and capacity for enforcing such laws in case of their existence. This article tries to provide more explanation for these points.
\end{abstract}

Keywords: environmental information, social information, lending decisions, laws

\section{Brief Introduction}

This article discusses the role of banks as a user, instead of only a producer, of environmental and social information released by companies, which are applying for loans. This aspect distinguishes banks from companies acting in other sectors such as industry. As Crawford and Williams (2010) mentioned, producing and using such information makes banks forefront players in the field of social and environmental disclosure practices. Due to their role in financing companies' activities, banks are able to stimulate companies to control environmental, social and economic impacts of their activities (Moyo \& Rohan, 2006). In order to do so, banks "must integrate environmental and social impacts as part of core investment risk evaluations" (Barako \& Brown, 2008, p. 312). As such, it is reasonable to think that some of banks' decisions are likely to be affected by environmental and social information released by companies seeking loans, and this in turn influences banks' performance and relation with their stakeholders.

\section{Using Environmental Information in Lending Decision}

Considering the issue of environmental disclosure, the relationship between banks and environment can be seen through their correlation (both; banks and environment) with economy. On one hand, it is undisputable fact that banks play a major role in economic sectors by financing companies acting in these sectors (Campbell \& Slack, 2011). In providing their services as intermediaries between borrowers and providers of money, banks are the most important channel to provide such service (Jeucken, 2001). Environment, on the other hand, is claimed to be vital to the existence of economy itself and life at large. Economic system is derived from ecological system, which provides natural sources to economy and receives and accommodates waste material, and thus, taking environmental issue into consideration is very important to the continuous of economic activities and life itself (Jeucken, 2001). As such, banks' activities can be influential to, or affected by, environment and this influence can be either negative or positive, on both banks and environment. The attention to the negative or positive role, financial sector can play, in environmental issue has increased since 1990s (Thompson, 1998), and this attention has become stronger and widely paid by many information users.

The impact of banks' activities upon environment can happen in a direct or indirect way. The first one happens by consuming energy, water, paper, etc. during the daily work of banks. Both; banks and environment as well, 
can benefit from efforts of conservative use and reuse resources and waste disposal (Coulson \& Monks, 1999). For example, Jeucken (2001) mentioned the case of one UK bank which controlled its consumption of energy to nearly the extent of $25 \%$ during four years, and as a result, the bank saved about fifty million Euro. The second way, that environment can be affected by banks' activities, is through loans banks provide companies with. Banks are capable of influencing environment by providing loans to, or withdrawing them from, companies which their activities have some environmental consequences (Cowton \& Thompson, 2000; Gray \& Bebbington, 2001; Campbell \& Slack, 2011). Granting loans can be resulted in environmental risks (Deegan, 2004) when loans are provided to companies pollute environment. On the other hand, banks can exploit their position as lenders to ensure that their loans benefit environment and companies (borrowers), as well as banks themselves. Providing loans to companies, which consider environmental issue in their activities, (for example by financing the process of purchasing equipment of preventing pollution) benefit environment (by preventing a potential damage), companies (by avoiding penalties and unfavourable reaction of costumers), and banks (in shape of a new and more saver market). Thompson (1998) pointed out to some attempts of banks to encourage companies to conduct good environmental practices. For example, initiative of Barclays bank in 1997, which introduced an environment loan facility, encourages any projects benefit environment directly or indirectly. Coulson and Monks (1999) also mentioned the case of National Westminster bank, which offers loans with competitive fixed rate to companies considering the impact of their activities on environment, and working to prevent, or lessening any possible damage.

In addition to the fact that environment benefits from such initiatives, banks have some advantages in dealing with companies which are considered environmentally responsible. Thompson (1998) indicated direct and indirect benefits banks might gain from "Green market". Direct benefits can be gained from making transactions with companies considered to be related to environment and environmentally responsible by having less credit risk and loan loss, whereas indirect benefits can be obtained by enhancing banks' image, in the eyes of public, by appearing in a picture of banks environmentally responsible. On the other side, companies also have some benefits to gain. Coulson and Monks (1999) highlighted the benefits companies gain from taking environmental issues into consideration. Such benefits include "quick and easy loan provision, reducing costs of loan negotiations and more favourable loan conditions."(Coulson \& Monks, 1999, p. 9) Another important advantage was also mentioned is a free advice on environmental management (provided by banks to those companies), which potentially influences the quality of risk management and success of companies as a whole.

Lending decisions are very important decisions, and they require assessing and managing credit risk. Assessing the potential risk of the credit is based generally on gathering and analysing information related, mainly, to the client seeking loans. Financial information is traditionally treated as a major part banks look at and consider in the process of evaluating borrowers' applications. Yet, environmental information has become (especially in developed countries) an essential part of risk criteria of many banks. Overall, it can be said that banks have the power to encourage, or push, companies to be careful with environment (and disclose environmental information about their activities), as Gray and Bebbington (2001, p. 208) stated "Ultimately, financial institutions have the greatest power over organisations, can greatly influence them in positive ways and profoundly hinder them in negative ways.". However, the question might be posed here is that: do banks willingly interested in protecting environment and exploit their position, as money provider, to compel companies to take care of environment in their activities?

In general, banks are not interested in playing the role of environmental regulators (Coulson \& Monks, 1999), or environmental policemen (Thompson, 1998). In effect, they have to be aware of environmental consequences of their lending decisions because, as environment is affected by such decisions, environment in return has an impact upon banks to the extent that it may constitute a real threat to their operations. There are three types of risks, resulted from lending decisions, environment can cause to banks (Thompson, 1998; Campbell \& Slack, 2011). These risks are: indirect risk, direct risk, and reputational risk. The first risk emerges when a borrower causes damage to environment, and being exposure to many costs as a result including: fines cost of cleaning up contaminated sites, cost of complying with increased environmental legislations, and losing revenues because of bad reputation. These losses and costs will impair the ability of the borrower company to repay loans, and may end with bank losing its loans. The second kind of risk, banks are likely to encounter because of their lending decisions, affects banks directly, when banks incur the liability of cleaning up the contaminated sites owing to insolvency of the borrower. This is because of the increased legislations, which treat the lender who has taken security (such as land) in these cases as a responsible party for remediation cost. The problem is that, in some cases, banks do not loss just their loans, but they have to pay the cost of remediation which can be more than the amount of the original loan itself. The last risk might result from lending decisions is reputational risk, when 
banks become known as irresponsible in regard to environmental issues, owing to their finance to companies considered polluters to environment. Such reputation might generate unfavourable reaction from costumers, media, pressure groups, and governmental bodies in some cases. This last kind of risk is argued to be different to other two risks, and more difficult to gauge its financial consequences, since its effect may take some time and emerge in future when banks lose their ability to attract new customers (Thompson, 1998).

Gray and Bebbington (2001) mentioned the case of Fleet Factors where the lender were found responsible for cleaning up the contaminated land, because the bank participated in the financial management, and was able to impact the company's treatment of hazardous wastes. The authors noted that becoming responsible did not even entail the bank to exercise its capacity to influence company's decisions. Such case gives an example to the serious consequences which might be resulted from ignoring the possible negative impact of banks' loans on environment. As such, responding to those three risks and their possible impact on environment, the attitude of banks towards environment has developed considerably to be more caution and responsible. According to Coulson and Monks (1999), US bank surveys (following the case of Fleet Factors) indicated that banks had changed their policies in regard to lending process, the matter which resulted in refusing some loan applications on the bases of environmental consideration, and also excluding some industries from future operations of banks because of the negative impact of the activities of these industries on environment. At international level, Gray and Bebbington (2001) indicated the result of a worldwide survey on banks (conducted in 1995), where most of banks surveyed found to be deeming environmental issues as an influential to their business, and thus they take environmental risks into their consideration in their assessments.

As a result of increased awareness of banks in regard to the importance of environment to their business, some steps were taken as a response to this importance. First, banks include environmental issues in their financial negotiations (Coulson \& Monks, 1999). The authors mentioned the case of Elm Energy companies as an example of this, where the company spent more than a year in its financial negotiation with a bank because of environmental concerns in relation to the project of the company. Second, banks started to apply a policy of refusing to finance any projects have a potential damage to environment, as the case of the co-operative banks (Thompson, 1998), and in some cases, excluding particular industries from the list of potential borrowers, due to the obvious negative impact of their activities on environment. Third, standard for assessing environmental risks has been introduced, as the case of HSBC (Campbell \& Slack, 2011). One good example of the steps, implemented by some banks in evaluating funding requests, has been mentioned in the article of Coulson and Monks (1999). Those steps include considering land (if there is a possibility that the land will be contaminated, and whether such contamination will cause harm etc.), appraisal of the client's processes (evaluating operations conducted by the company so as to discover any potential risk in such operations), and client's management (how well the client manages all of these issues when discussing the business process) since some companies have a good management which can minimise the likelihood of any bad consequences of their operations.

There are many individual studies confirmed the increased interest of banks in environmental issue. Thompson (1998) examined the case of twelve UK banks in regard to their lending decisions and their relation to environmental issues. Findings of the study indicated-inter alia- that the importance of environmental issue to banks' lending decisions has been increasingly recognised by banks, and the main method to integrate environmental consideration and lending procedures is by changing the criteria of credit risk. In another study, with bigger sample (57 banks in UK, including foreign banks), Thompson \& Cowton (2004) tested the relationship between lending decisions and banks' demand for environmental information, and found that banks had some interest in environmental information released by companies seeking loans. A desire for seeing such information more developed is found but on narrow bases rather than more comprehensive forms of environmental disclosure. At continental level, Weber (2005) examined the case of 129 European banks and financial service organisations in terms of integrating sustainability into their policies, strategies, products, services and processes. Only what so-called alternative banks (banks which deem having a positive influence on the environment as one of their principal goals) were found to be integrating sustainability into their general business strategy. Therefore, all their products were in line with sustainability notion. The potential motivations for such conduct, as the author mentioned, can be financial motivation, personal concern, philosophical background, or missions of public bank owners. Considering the issue of reporting pertaining to integrating environmental risks into corporate lending, the same author, Weber (2010) chose Canada as a place to conduct his study in. He found that Canadian banks and financial institutions perform well in regard to both; integrating environmental risks into credit risk management, and sustainability issues as a whole.

In contrast, the case in developing countries seems to be different. Financial information is still a core of banks' interest in regard to lending decisions. Walid, Husni \& Abdalla (2011) investigated the methods used by the 
credit managers and analysts in credit facilities administrations at the Jordanian Commercial Banks (listed in Amman Stock Exchange) to evaluate the credit worthiness of the credit facilities demanders in the process of lending decisions. He also investigated the limitations of the better use of financial analysis methods in enhancing such decisions. The sample of the study represented $84.6 \%$ of all credit managers and analysts. Findings indicated the increased use of some financial and accounting methods, indicators and models. The authors recommended taking the financial and accounting methods, indexes, and models into consideration in the process of lending decisions. Moreover they highlighted the importance of using different kinds of financial ratios and financial failure prediction models so as to have a sound credit policy. However, this study did not address environmental issues in the process of appraising the position of the client who seeks a loan, and whether it is in the interest of the bank (and environment) to grant a loan to such client. No single indication was made to the impact of the environment on financial indicators, although many cases, mentioned in different articles, illustrated that relying exclusively on financial statements in lending decisions can be a big mistake. Coulson \& Monks (1999), in highlighting the importance of addressing environmental information in lending decisions, mentioned a case of Acme Metals Limited which applied for overdraft from its bank. The bank analysed the financial information (business plan, projections, cash flow forecast etc.) and non-financial information (track record, management quality etc.). The result of the analysis was encouraging, and then the bank agreed on the overdraft request. Some months later, the company faced financial difficulties, and the bank agreed on increasing the amount of overdraft. With another problems the company faced, it was decided to sell the site belongs to the company, to repay the bank's facility. During sell process, it was discovered that the site is heavily contaminated, and the cost of the clean-up is estimated to be much more than the expected value of selling the site itself. The authors commend on this case by concluding that such result was because of omitting environmental issues.

Based partly on the foregoing, it can be said that there are some explanatory factors behind the attitude of banks with respect to considering environmental issues in lending decisions. First, environmental laws and their increased legislations is the main engine for taking care of environment in bank business, especially in lending decisions. Refusing to lend companies with environmental problems can be attributed to the developments in environmental legislations (Coulson \& Monks, 1999). Fear of losing their loans (indirect risk) and their reputation (reputational risk), as well as, becoming responsible for the clean-up of the contaminated sites (direct risk), is the main reason why banks consider environmental information before reaching the final decision in the process of lending. Thompson and Cowton (2004, p. 215) stated "The consideration of environmental issues in bank lending operations is prompted mainly by a concern to manage risk rather than to exploit lending opportunities or as a means of fulfilling their social responsibilities". They argued that "banks are not so much interested in the impact of bank lending upon the environment as in the impact of the environment (as filtered by regulators, etc.) upon bank lending." A manager of a major retail bank, interviewed in the study of O'Dwyer (2003, p. 534) stated "it had to be careful to manage environmental risk in lending". Even though considering environmental issues in business world offers banks opportunities (green market) for gaining financial benefits, banks focus more on risks than possible profits (Thompson, 1998).

Second, the mechanism of implementing environmental legislations effectively is very important factor (especially in developing countries) in pushing banks to concern themselves with environmental issues. Without an effective mechanism, legislations are not more than just wards. Third, pressure groups are a major party in constituting reputational risk to those banks which ignore environmental consequences of their lending decisions. The stronger environment group the more environmentally conservative loans banks grant. Forth, there is no doubt that availability of environmental information and its quality are a precondition for any consideration of environmental information within lending decisions. There is no much to do by banks when accounting practices, conducted by companies seeking loans, do not include producing and releasing environmental disclosure, as the case in some developing countries. This point is very clear in the comment of one of the corporate managers interviewed in the study of Belal and Owen (2007, p. 481) who stated "In Bangladesh, where companies do not disclose basic financial information properly and credibly, I'm not sure whether we can talk about things like social disclosures.". This point leads to the fifth and last factor, which can influence the matter of taking environmental issues into consideration in lending operation. That is the lack of qualified employees in the bank, in terms of how to address environmental information and use it in the process of leading decisions. For reasonable reasons, it can be said that these factors seem to be in a negative side in developing countries, and this might provide an explanation for omitting or downplaying the importance of environmental issue in lending operations in this kind of countries.

\section{Using Social Information in Lending Decision}

Thompson and Cowton (2004, p. 216) concluded their investigation (of the case of UK banks in relation to using environmental information in lending decisions) by providing a suggestion, as a future study, of investigating the 
views of bankers in respect to usefulness of elements of social accounting in lending decisions, other than environmental information. The authors found it interesting to know whether banks are willing to use social information, in their lending decisions, as they are producing this information. In other words, is using social information as important as producing it. Posing such question reflects the lack of studies, which consider the materiality of social information (produced by companies seeking loans) to lending decisions.

Yet, there are references of some interest in social information. Solomon and Solomon (2006), considering the extent to which institutional investors integrate social, ethical and environmental disclosure into their investment, found- inter alia- that their results were in line with that of Miles, Hammond \& Friedman (2002) in that mainstream financial community has increasingly become more interested in social, ethical, and environmental disclosure. Weber (2005) found also that social aspects of sustainability have been considered in work of European banks. In contrast, Murray, Sinclair, Power \& Gray (2006) examined if there is an association between social and environmental disclosure and the financial market performance of the UK's largest companies, and found no direct association between such disclosure and share returns. Campbell and Slack (2011) confirmed such result after investigating the attitudes of UK sell-side bank analysts, since financial analysts are described as capital market gatekeepers and one of key stock market agents ( Aerts, Cormier \& Magnan, 2008). In the case of banks, a major 'player' in stock markets (Deegan, 2004), Thompson and Cowton (2004) found that although some interest in environmental information was found in lending decisions of this group, no interest has been expressed by the same group towards gauging some things including periodic net social contribution.

From another angle, it can be argued that those studies which indicated some interest in social information, in terms of its use in investment and lending decisions, may be affected by not distinguishing environmental information from other categories of social disclosure, in which some results of social information might generated on the case of environmental information, and vice versa . i.e. using one kind of those disclosures as a substitution of the other. For instance, Deegan (2004), emphasised the increased demand of banks for social and environmental information, but when he proceed to give an example of that, just environmental risk and liability were mentioned, and companies' concern was just "to demonstrate to a bank or other lender that there are no hidden environmental liabilities that could become the responsibility of the lender or that could diminish the value of the property or organisation." (Deegan, 2004, p. 93). The other evidence, which the author gave as an example of the demand for social and environmental information, was also about environment, specifically a study of the materiality of environmental risk to Australia's finance sector. Last, even though he concluded the sixth part of his article (about the changes in the market's demand for, or use of, social and environmental information) by expressing his belief that there is clear evidence that capital market participants are demanding and using environmental and social performance information, social information mentioned was nothing but environmental one.

Apart from environmental information, other components of social information, such as: human resources and community involvement, provided by companies seeking loans, have not (to the best of our knowledge) been considered as a potential factor influencing bank decisions in regard to loans. It is unusual to find banks refused to finance a company because it has not involved in the community activities for instance. In line with this, there is a lack, if not absence, of studies focusing on the issue of considering social information (excluding environmental one) in bank lending decisions. Indirectly, it is possible to find some studies' results, which can be construed as an indicator of taken social and environmental information into consideration in lending decisions. For example, in the study of Pessarossi, Godlewski \& Weill (2010), it was investigated whether the desire of foreign banks, to participate in syndicated loans to corporate borrowers, is affected by information asymmetries. In accomplishing this aim, the authors focused on tracking the influence of ownership concentration on the participation of foreign banks in a loan syndicate. The sample included syndicated loans given by 79 Chinese banks and 293 foreign banks to Chinese borrowers during the period 2004-2009. The study unveiled a negative association between the greater ownership concentration (of the borrowing firms) and the extent of foreign banks participation in the loan syndicate. This result supports the possibility of taking, or being prepared to take, social and environmental information into account in lending decisions, since many studies proved that the concentration of ownership increases information asymmetries, and has a negative impact upon the extent of social and environmental disclosure, the matter which in turn affects the company's chance of being granted a loan. Another finding of Pessarossi et al. (2010) is that increased financial leverage does not also encourage the participation of foreign banks. This finding can be interpreted similarly to the previous one, as indirect evidence of the potential use of social and environmental information in lending decisions.

In order to understand why there is an absence or a lack of banks' use of social information in their lending decisions, at least in the same degree of using environmental information, it might be useful to look back at the 
case of environmental information. It should be investigated why the attention was paid to such information, what the motivations of that attention, and the applicability of these motivations in the case of social information.

We have seen previously that banks have an impact upon environment directly (in form of consuming energy, water, paper, and so on) and indirectly in shape of loans provided to companies, which their activities have environmental consequences. Banks disclose information about this impact for several reasons mentioned in details in the previous pages. In the same vein, and as a result of providing loans, environment has also an impact upon banks' business. The later impact consists of three kinds of risk, namely; indirect risk, direct risk, and reputational risk. These risks constitute a real threat to banks' business, and it can lead to its demise. Thus, banks pay a great attention to such risks, and have no alternative option but to consider environmental information of their clients before taking lending decisions. It is obvious that law and legal legislations were behind the first two kinds of risk (indirect and direct risks). By law, banks might not just lose their loans, but also be responsible for the clean-up of the contaminated lands, which its cost can exceed the amount of the original loan itself. The last kind of risk, reputational risk is more likely to be caused by many parties such as pressure groups, media, and so on. Such potential risks are likely to lead ultimately to an improvement in companies' environmental performance and disclosure, as it is argued that banks, because of their position as money provided, have the power to make a pressure on companies to be environmentally and socially responsible (Crawford \& Williams, 2010), and to improve the quality, and extend the volume, of social information to the benefit of all (Thompson \& Cowton, 2004). However, what should be kept in mind (to understand the case of social information) is that the motivation behind conducting such role by banks is only its focus on their own interest at the first place.

Thompson and Cowton (2004, p. 215) stated "Indeed, it could be argued that banks are not so much interested in the impact of bank lending upon the environment as in the impact of the environment (as filtered by regulators, etc.) upon bank lending.". This argument seems to be applicable in the case of social information as well. Banks might care more about the impact society can have on banks' business and whether such impact can cause a threat to their business, rather than considering its impact on society. Similar to the case of environmental information, banks have an impact on society, directly (through community involvement, human resources, etc.) and indirectly (through loans provided to companies, whose their activities have social consequences). Banks produce information about this impact and emphasise, as it is evidenced by many studies, the positive role banks play in this regard. By the same token, society also has an impact on banks' business, but this impact is not as severe as that in the case of environment. There are two risks can be resulted from not considering social impacts loans can make to society. Indirect risk (resulting from a client being unable to repay the loan due to committing social violations and paying some costs such as compensations to his opponents) and reputational risk caused by some active groups in society. The first risk can be mitigated by taken over securities, while reputational risk is less likely to occur, since financing companies is often not seen as a potential participation in the violations. It is obvious that the direct risk does not exist in this case, and the reason for that is the absence of laws which make banks responsible for social liability, similar to environmental liability. The financial role of banks (as a financier of the offender) is normally not considered in courts. Coulson and Monks (1999, p. 3,4) stated "A primary issue for lenders has been their potential to be held liable for environmental damage attributed to their corporate borrowers". As such there is no primary issue for the lenders in case of social information, and thus no attention to be very careful with the potential social impact of lending decisions.

Based on the foregoing, three reasons can be provided to explain the lack or absence of banks' interest in considering social information in their lending decisions. Firstly, the absence of public awareness in recognising the role of banks, as a third party, in social violations committed by their clients, downplays the materiality of any correlation might link banks to any kind of responsibility. This led to the absence of any perceived pressure on banks to consider social issues in their lending decisions or at least to put pressure on their clients to provide more social information. It is argued that banks can encourage, or push, their client to behave in social responsible manner and to extend their social disclosures, but such proposed role seems not in mind of bankers. Banks are not likely to be willing to play the role of social regulator, policeman or volunteer. This was made clear by one of the interviewees in the study of O'Dwyer (2003, p. 534) who stated "If we decide we are going to be proactive and do a decent thing (a community crime prevention initiatives), we are not doing it for moral reasons. We are doing it for business reasons... it is important that we get maximum benefit from it...otherwise we will not do it." Moreover, In addition to the argument of Thompson and Cowton (2004) that banks is interested just in the case where they are likely to be affected, also there is also a support for their notice that banks can obtain extra information from their clients in a private way, and thus they are not willing to put a pressure on their clients to disclose more social information publically. The study of Solomon and Solomon (2006) revealed that when social, ethical, and environmental disclosures were perceived by institutional investors 
as insufficient, for their portfolio investment decisions, there was a development of private social, ethical, and environmental disclosure channels between institutional investors and their investee companies.

Second possible reason for the lack or absence of banks' interest in using social information in their lending decisions is the difficulties in measuring the damages resulted from financing companies, which do not behave in socially responsible way. This matter makes it hard to target banks for such activity. In environmental issue, damages are basically material, measurable, and can be expressed in numbers. In contrast, how can it be assumed that banks financing a company which, for example, exploits their employees or does not involve in society (through donations, scholarships for student, and so on) are damaging the society by their finance, and how can the "damages" be measured?

Thirdly, and even more importantly, the absence of legal responsibility of banks in the situation of social violations, committed by borrower companies, can be deemed as a main cause of the issue discussed. It can be argued that there is a weakness in the capacity of laws in tracking all the elements which contribute in violations. It might be reasonable to think that banks financing a company which, for example, use children labour, should be considered as partners in such crime, because they enable such company to commit this violation. However, it seems that laws concentrate only on the last offender, ignoring the other actors who participated in the violation but in less obvious way. This method can be noted in many other legal cases. For instance, alcohol is found to be a cause of many crimes such as: rape, murder, theft, mugging, assault, domestic violence, vandalism, and causing a high proportion of road accidents. Yet, law does not punish companies producing alcohol; rather it considers only the person who committed the crime. No responsibility can be tracked in regard to those companies. Another example, for the weakness of law in judging some issues, is the case of the pregnant women. They drink Alcohol knowing that such action will result in some serious illnesses in their babies before and after the birth such as: Fetal Alcohol Syndrome and Fetal Alcohol Spectrum Disorder, which cause many health problems, and death in some cases. Yet, there is no legal punishment for such behaviour. These are just examples reflecting what can be seen as points of weaknesses in legislations. Confining the responsibility to just one party (and sometimes no one), and excluding others who participate in one way or another in causing the problem, may explain the attitude of banks towards the idea of using social information in their lending decisions. Moving to advanced position in this issue may not be easy by law. Other motivations such as religion might make difference in this field, and Islamic banks can be provided as an example. There is a saying of prophet Mohamed (peace be upon him) outlining the view of Islam in regard to responsibility. The Prophet Muhammad (peace be upon him) said: "Allah has cursed Khamr (intoxicants - alcohol, wine etc.), the one who drinks it, the one who pours it for others, the one who sells it, the one who buys it, the one who makes it, the one who it is made for, the one who carries it, the one who it is carried to and the one who consumes the money from its sale." (Hadithaday, 2010).This saying indicates that the sin includes all of those who participated, in one way or another, in drinking Alcohol at the end. Therefore, everyone is responsible since he contributed in the existence of the action. Applying such Islamic teaching, Islamic banks are not "involved or have material ownership in any prohibited business activities. These include alcohol, tobacco, pork-related products, conventional financial services (that is, riba-based financing), and the entertainment business" (Gray \& Ismail, 2007). All of these activities mentioned are including some social effects considered to be harmful to individuals and society at large, even though they can be considered profitable activities to borrowers and banks. As such, it can be said that Islamic banks consider social information in their lending decisions because of its different conceptions of responsibility.

\section{Conclusion}

Possibility of using environmental and social information by banks, in the process of lending decisions, can be determined and justified by different factors. These factors are related to legal environment, pressure groups, banks' clients, and banks themselves. Legislations (especially in more developed countries) are the main engine of convincing banks to consider environmental information in their lending decision. Yet, creating the same case in regard to social information seems to exceed the capacity of laws. Other factors can be suggested instead, such as religious teachings. The process of making lending decision cannot be understood without taking the impact of external environment which includes legal environment, awareness of society, ability of clients to produce such information, and perception of environmental and social responsibility.

\section{References}

Aerts, W., Cormier, D., \& Magnan, M. (2008). Corporate environmental disclosure, financial markets and the media: An international perspective. Ecological Economics, 64, 643-659. http://dx.doi.org/10.1016/j.ecolecon.2007.04.012 
Barako, D. G., \& Brown, A. M. (2008). Corporate social reporting and board representation: Evidence from the Kenyan banking sector. Journal of Management and Governance, 12, 309-324. http://dx.doi.org/10.1007/s10997-008-9053-x

Belal, A. R., \& Owen, D. L. (2007). The views of corporate managers on the current state of, and future prospects for, social reporting in Bangladesh: An engagement-based study. Accounting, Auditing \& Accountability Journal, 20, 472-494. http://dx.doi.org/10.1108/09513570710748599

Campbell, D., \& Slack, R. (2011). Environmental disclosure and environmental risk: Sceptical attitudes of UK sell-side bank analysts. The British Accounting Review, 43, 54-64. http://dx.doi.org/10.1016/j.bar.2010.11.002

Coulson, A. B., \& Monks, V. (1999). Corporate environmental performance considerations within bank lending decisions. Eco-Management and Auditing, http://dx.doi.org/10.1002/(sici)1099-0925(199903)6:1<1::aid-ema93>3.0.co;2-m

Cowton, C. J., \& Thompson, P. (2000). Do codes make a difference? The case of bank lending and the environment. Journal of Business Ethics, 24, 165-178. http://dx.doi.org/10.1023/A:1006029327264

Crawford, E. P., \& Williams, C. C. (2010). Should corporate social reporting be voluntary or mandatory? Evidence from the banking sector in France and the United States. Corporate Governance, 10, 512-526. http://dx.doi.org/10.1108/14720701011069722

Deegan, C. (2004). Environmental disclosures and share prices - a discussion about efforts to study this relationship. Accounting Forum, 28, 87-97. http://dx.doi.org/10.1016/j.accfor.2004.04.007

Gray, R., \& Bebbington, J. (2001). Accounting for the environment. Thousand Oaks, Calif, Sage Publications.

Gray, R., \& Ismail, A. (2007). Regulating Islamic capital markets. In: ARCHER, S. \& KARIM, R. A. A. (Eds.) Islamic Finance: The Regulatory Challenge. Singapore: John Wiley \& Sons (Asia) Pte Ltd.

Hadithaday. (2010). $\mathrm{HaD} 201-$ Allah has cursed Alcohol [Online] Available: http://hadithaday.org/those-who-deserve-the-curse/had-201-\%E2\%80\%93-allah-has-cursed-alcohol/ [Accessed 13/02/2012].

Jeucken, M. (2001). Sustainable finance and banking: the financial sector and the future of the planet. London, Earthscan Publications Ltd.

Miles, S., Hammond, K., \& Friedman, A. L. (2002). Social and environmental reporting and ethical investment, ACCA Research Report No. 77. London: Certified Accountants Educational Trus.

Moyo, T., \& Rohan, S. (2006). Corporate citizenship in the context of the financial services sector: what lessons from the Financial Sector Charter? Development Southern Africa, 23, 289-303. http://dx.doi.org/10.1080/03768350600707744

Murray, A., Sinclair, D., Power, D., \& Gray, R. (2006). Do financial markets care about social and environmental disclosure? Further evidence and exploration from the UK. Accounting, Auditing \& Accountability Journal, 19, 228-255.

O'Dwyer, B. (2003). Conceptions of corporate social responsibility: The nature of managerial capture. Accounting, Auditing \& Accountability Journal, 16, 523-557.

Pessarossi, P., Godlewski, C. J., \& Weill, L. (2010). Foreign bank lending and information asymmetries in China. BOFIT Discussion Papers, 2010, 0_1-0_1,3-23.

Solomon, J. F., \& Solomon, A. (2006). Private social, ethical and environmental disclosure. Accounting, Auditing \& Accountability Journal, 19, 564. http://dx.doi.org/10.1108/09513570610679137

Thompson, P. (1998). Bank iending and the environment: policies and opportunities. International Journal of Bank Marketing, 16, 243-252. http://dx.doi.org/10.1108/02652329810241384

Thompson, P., \& Cowton, C. J. (2004). Bringing the environment into bank lending: implications for environmental reporting. The British Accounting Review, 36, 197-218. http://dx.doi.org/10.1016/j.bar.2003.11.005

Walid, Z. S., Husni, A. K., \& Abdalla, A. D. (2011). The utilizing of financial analysis in rationalising decision of granting credit facilities. International Research Journal of Finance and Economics, 26-34. 
Weber, O. (2005). Sustainability benchmarking of European banks and financial service organizations. $\begin{array}{llll}\text { Corporate Social Responsibility and Environmental Management, } 12, & \text { 73-87. }\end{array}$ http://dx.doi.org/10.1002/csr.77

Weber, O. (2010). Sustainability and environmental risk management in Canadian banks and financial service institutions A global comparative study. SSRN eLibrary. 